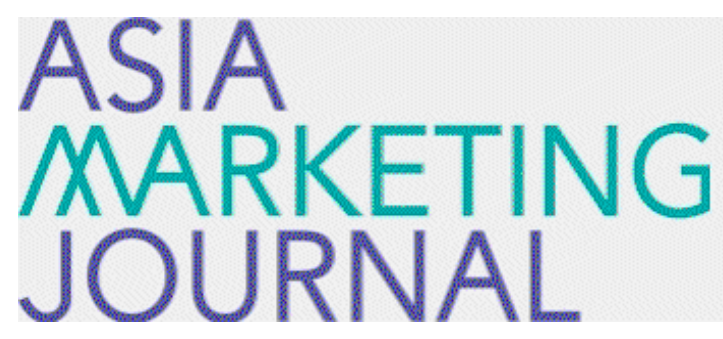

ASIA MARKETING JOURNAL

Volume 18 | Issue 1

Article 4

4-30-2016

\title{
The Impact of Patent Infringement Litigation on Customer-Based Brand Equity
}

Ju Pin Chou

Jeonpyo Noh

Jiyeon Choi

Follow this and additional works at: https://amj.kma.re.kr/journal

Part of the Marketing Commons

\section{Recommended Citation}

Chou, Ju Pin; Noh, Jeonpyo; and Choi, Jiyeon (2016) "The Impact of Patent Infringement Litigation on Customer-Based Brand Equity," Asia Marketing Journal: Vol. 18 : Iss. 1 , Article 4.

Available at: https://doi.org/10.15830/amj.2016.18.1.55

This Article is brought to you for free and open access by Asia Marketing Journal. It has been accepted for inclusion in Asia Marketing Journal by an authorized editor of Asia Marketing Journal. 


\title{
The Impact of Patent Infringement Litigation on Customer-Based Brand Equity
}

\author{
Ju Pin Chou* \\ Jeonpyo Noh** \\ Jiyeon Choi***
}

With continuous news headlines related to patents in the public media, awareness of patents' value is spreading, and patents are valuable not only to a firm but also to consumers. Therefore, this study makes an effort to explore the theoretical mechanism of the effects of patent infringement litigation (PIL) on customers. More specifically, this study examines the influence of PIL on customer-based brand equity (CBBE) and brand innovation image (BII). Based on this study's findings, PIL's outcomes directly affect BII, which in turn indirectly affects $\mathrm{CBBE}$. That is, people will evaluate a winning brand as a highly innovative brand, which contributes to higher brand equity. However, in regards to PIL's direct effect on CBBE, there are some differences between Apple and Samsung. In the case of Apple, the winner image positively affects only one dimension of CBBE, brand loyalty, while for Samsung, the plaintiff's image negatively affects brand loyalty.

Key words: Customer-Based Brand Equity (CBBE), Brand Innovation Image (BII), Patent Infringement Litigation (PIL), Apple, Samsung

\section{Introduction}

Patent litigation has recently received more attention than ever with the increase of possible monetary damage to firms. Bessen et al.
(2015) estimated that $\$ 385$ billion was spent on patent litigation between 1984 and 2009. For example, Apple sued Samsung for approximately $\$ 2$ billion, arguing that Samsung violated some of its patents (Netzer and Sambandam, 2014a). As researchers have realized the impact and

\footnotetext{
* Master's Graduate, Department of Design Management, Yonsei University at Wonju Campus

** Professor of Marketing, Yonsei University at Wonju Campus (nohj@yonsei.ac.kr), Corresponding Author

*** Ph.D. Candidate, Department of Business Administration, Yonsei University at Wonju Campus
} 
magnitude of patent litigation, many studies have been conducted on the strategic use of patents. Previous studies suggested that some driving forces like copy prevention, fence and thicket building, attaining licensing income, and rewarding $R \& D$ personnel could motivate firms to seek patents (Rudy and Black, 2015).

However, patents litigation not only affects a firm's financial performance by licensing or litigation, but also serve as a crucial force for company-driven product innovation. In the existing literature, patents have been found to have a high correlation with a firm's performance and innovation (Kortum and Lerner 2000; Bloom and Leenen, 2002). Under the increasing levels of global competition, a firm's ability to generate constant innovations may be more important than maintaining competitive advantages, such as higher quality products with a lower cost and rapidly releasing products into the markets to follow the mainstream. This kind of ability helps a firm to differentiate itself from others and leads to a higher financial performance. On the other hand, innovation ability is a standard by which people evaluate a brand. Consumers value innovation greatly and, indeed, care deeply about it. They respect companies and brands that they see as pioneering and striving to improve their world. Nevertheless, the previous studies dealing with patents' impacts are limited to the objective financial performance of the firms rather than focusing upon consumers' perspectives. Therefore, this study attempted to provide useful insights to better understand a relationship between PIL and its effects on consumers.

Through the emergence of PIL and higher awareness of a patent's value, a patent may impact consumers more directly and become a new index for consumers to evaluate a brand. Based on the changes mentioned above, this study focuses on PIL's marketing effects, that is, the effect on consumers rather than on the performance of the firm. Even though there are limited studies relating PIL to the consumer's brand attitude, it seems that PIL has already become a marketing strategy in practice. Samsung Australia's mobile chief said that far from killing its Galaxy Tab 10.1, Apple's court case was almost a blessing in disguise, making the product a 'household name'. PIL in this case can be seen as one part of buzz marketing, which creates buzz and improves brand awareness.

This study aims to discover PIL's marketing effects by conducting both quantitative and qualitative research, analyzing PIL's effects by examining customer-based brand equity (CBBE) and brand innovation image (BII). More than 400 consumers are investigated, and the relationships mentioned above are examined in the collected data. Based on the findings, the present study attempts to prove whether patents have an impact upon improving the firms' financial performance and innovation, and managing brand values from the perspective of consumers. 


\section{Literature review}

\subsection{Patent and patent infringement litigation (PIL)}

According to the World Intellectual Property Organization (WIPO)'s definition, a patent is an exclusive right granted for an invention, which is a product or a process that provides, in general, a new way of doing something or offers a new technical solution to a problem. Once the patent is granted, the exclusive right is given to the patentee, which can prevent others (potential infringers) from making, using, selling, or distributing the patented invention without permission (Hong, 2009). Patents play an essential role for firms in using to capture rents from innovation and have been shown to spur greater innovation (Mazzoleni and Nelson, 1998). However, a patent does not directly give patentee the right to practice the invention; rather it grants the right to preclude others from using, manufacturing, or selling a product or service that uses the patented invention (Rudy and Black, 2015). Because patents do not give affirmative rights to the patentee, competitors are able to 'invent around' the patent (Mansfield et al., 1981), which has forced many firms to enhance the value of their intellectual property through strategic management initiatives, such as obtaining more patents to build 'patent fences' (Pisano, 2006).
On the other hand, patent infringement is the commission of a prohibited act with respect to a patented invention without permission from the patentee. Patent infringement litigation (PIL), in general, is a lawsuit involving a company or individual who sues another party for patent infringement, leading to a legal battle between two parties: the patentee and infringer or the plaintiff and defendant, respectively. Indeed, when two parties sue each other several times, PIL is usually expressed as a patent lawsuit, patent war, patent battle or patent dispute in the media. PIL can generally only be enforced through civil lawsuits, although some countries such as France and Austria have criminal penalties for wanton infringement (Lemley, 2005). Because the PIL processes vary between countries based on their particular patent laws, for better understanding in this study, the author roughly portrays the general PIL stages and introduces typical remedies for PIL by reviewing articles on the U.S. PIL process in the following context.

A patentee who prevails in a patent infringement case in court is entitled to two main remedies; an injunction and money damages. First, injunctions; permanent injunctions, preliminary injunctions and temporary restraining orders, which can be not only issued but also dismissed by courts. Due to the lengthy litigation processing time, especially in technological industries, patentees tend to seek preliminary injunctions to prevent infringers from 
selling or launching their products in the market. Second, there are two kinds of money damages: lost profits and a reasonable royalty. If a patentee cannot prove lost profits or can show only some lost profits, he or she may seek damages in the amount of a reasonable royalty on the remainder of the sales. There is no marking requirement when only method claims are asserted. Treble damages and attorneys' fees are especially worth mentioning. The court may order the infringer to pay up to three times the money damages if the patentee can show that the infringer's conduct was 'willful'.

According to Chien (2008), PIL has its unique six attributes: 1) Transnational: PIL is involved with different countries, companies, and markets. 2) Premeditated: PIL is usually planned to achieve commercial purposes, aimed at increasing revenues and order and reducing competition. 3) Large-scale: PIL often extends to many countries and regions at the same time. 4) Continuous: during the PIL process, trust in the infringer and the image of the infringer's management capabilities are damaged, and once this image is damaged, other companies may bring more unnecessary infringement litigation against the original infringer. 5) Systematic: PIL is connected with business strategy, and a standard system has developed. Companies often release related information, causing panic in the market and forming public pressure that makes the infringer weaker and the case easier to win. 6) Resource-rich: a company that in- tends to engage in PIL must meet rich financial resources, human resources, longevity.

With the characteristics mentioned above, the reasons for a company filing PIL become more complex. Somaya (2003) pointed out that the probability of litigation is mainly due to its correlation with the value of the patent. According to Cremers (2007), relatively valuable patents are more likely to be involved in litigation cases than the average patent. The patentee's ability to trade patents with potential infringers and to interact with them repeatedly appears to promote pretrial settlement and to prevent patentees from filing suits. Moreover, Bessen and Meurer (2008) warned that the losses of alleged infringers do not correspond to a transfer of wealth to patent holders; instead, there is a substantial joint loss of wealth. In sum, PIL can be said to cause more complex and unpredictable results from its verdict and damage from media exposure (PWC, 2011), whereas a patent mainly focus on fencing from competitors and attaining licensing income as a patent per se. Therefore, consumers could scarcely notice which company has useful patents as long as PIL information is exposed through a media to them. Accordingly, in order to identify consumers' subjective reaction to a patent, this study shed light on PIL effects.

\subsection{Litigation public relations}

According to Haggerty (2004), litigation public 
relations (litigation PR) is defined as the management of the communications process "during the course of any legal dispute or adjudicatory proceeding so as to affect the outcome or its impact on the client's overall reputation." As he suggests, litigation PR focuses on two objectives. The first one is to influence the outcome of litigation, perhaps by encouraging an early or favorable settlement or by pressuring the prosecution into bringing lesser or no charges (Fitzpatrick and Rubin 1995; Haggerty, 2004). The second is to protect the client's reputation before issuing a verdict, which can be regarded as one kind of reputation management. Reputation management refers to managing public perception of an organization or individual. It is about attitudes toward the individual and not particular knowledge itself. Therefore, an essential aspect of reputation management influences attitudes about the individual or corporation. Lee and Lee (2012) stated that negative rumors can dishonor a brand and damage relations with its customers. It is worth mentioning that litigation PR on the part of defendants is needed, especially in high-profile cases, because the media has an inherent bias in favor of plaintiffs and prosecutors (Hantler et al., 2004). Consequently, the media tends to portray lawsuits as victim versus villain. News and reports frequently lead with the plaintiff or prosecutor's allegations. If the defendant's responses are included at all, they appear well into the story. Thus, the defendant is forced to be on the defensive from the outset. In such situations, it would appear that litigation PR differs from the broader practice of public relations in several key aspects. First, litigation PR is highly dependent on media relations (Gibson and Padilla, 1999). Although the practice of public relations today involves far more than just mediated communication, litigation PR remains dependent on the media. It is because of the media's increased attention to lawsuits that litigation PR has become a necessity for many high-profile clients. Second, because typical public relations campaign strategies and tactics may not be appropriate and may even be harmful at certain times during a lawsuit, the legal strategy must take precedence. Third, litigation PR is regulated more than regular public relations because of the potential for prejudice within the legal process (Gibson and Padilla, 1999). However, the biggest difference may be the emphasis on one-way, asymmetrical communication. Because the law is adversarial in nature, creating a win-lose situation, the goal of litigation PR is to reinforce the legal strategy and theory of the case to ensure a win, while at the same time reducing damage to the organization's credibility and reputation.

\subsection{Brand innovation image (BII)}

In order to build a view of the "consumer innovation space," Thomas (2008) investigated 474 UK consumers between the ages of 18 and 65 years, and then conducted three focus groups 
with pre-family, family and post-family demographic groups and brought out six key indexes: (1) be a pioneer, (2) make my life easier, (3) create a buzz, (4) be approved by my peers, (5) give me a reason to trust you, and (6) understand my life. Together, these indexes form the concept of BII. Moreover, the research shows that consumers do value innovation highly and, indeed, care deeply about it. They respect companies and brands that they see as pioneering and striving to improve their world. They only have little time for companies and brands that don't deliver genuine innovation. In fact, consumers will participate heavily in creating buzz around an innovation they love, which in turn makes it seem more innovative. This kind of circle is called an 'innovation virtuous circle.' This study gives advice not to chase innovation for innovation's sake- if it won't make life easier and provide a benefit, then 'trash it.' BII here is about consumers' attitudes toward the brand, and not innovation itself. Consumer's perception of a brand performance has a significant effect on brand evaluation such as brand preference and purchasing intention (Jun et al., 2009). Since BII is as important as innovation itself to a firm, this study suggests that in addition to discovering the internal innovation in a firm by examining R\&D investment and patent sums, bringing out consumers' attitudes toward a brand's innovation through the use of a BII scale is critical as well.

\subsection{Customer-based brand equity (CBBE)}

Brand is important in the decision to purchase a smartphone (Netzer and Sambandam, 2014b). The specific marketing effects related to brand equity can be examined by both a financial and a consumer perspective. The former, financial perspective is based on firm outcomes, such as brand market share, revenue, and premium prices, or by a consumer's perspective, such as the consumer's brand image, awareness and attitudes (Keller, 1993; Ailawadi et al., 2003). The latter is so-called customer-based brand equity (CBBE), and according to Keller (1993), it is defined as "the differential effect of brand knowledge on consumer response to the marketing of the brand." Proponents contend that for a brand to have value, it must be valued by the customer. If the brand has no meaning to the customer, none of the other definitions are meaningful (Cobb-Walgren et al., 1995; Keller, 1993). Because the changes in firm outcomes are often aggregated consequences of customerbased brand equity, such as brand image and attitude (Ailawadi et al., 2003; Keller and Lehmann, 2006), much effort has been put into conceptualizing and measuring customer-based brand equity. As Keller (1993) explained, positive customer-based brand equity "can lead to greater revenue, lower cost, and higher profit”. This concept can also be adopted in the IT industry. For example, Samsung contended that since the demand and value of smartphones 
were not only being estimated as specific features, but brand should be considered as one of the primary features (Netzer and Sambandam, 2014a).

According to Ambler' et al. (2002), consumerbased perspective focuses on the customer's profitability, but that profitability is often caused by what the customer thinks about the brand. Thus, it has a basis in terms of their reliance on perceptions, beliefs, feelings, and attitudes (i.e. the customer's mind-set), which means this concept embraces consumers' temporary responses such as liking or preference and represents more prolonged measurement for brand value. Similarly, Keller's (2006) definition of CBBE underlines the differential effect that brand knowledge has on consumer response to the marketing of that brand. The current research therefore focuses on CBBE not attitude or liking. The reason for this is that CBBE is specialized in $\mathrm{ex}^{-}$ plaining image of a brand, enabling us to identify the effects of brand image in IT industry on its brand loyalty. Some people may like a brand with innovation image, whereas other may not. Although consumers prefer particular brand, the reasons should be different from individual to individual. By using CBBE, this study can identify more obvious relationships among information about PIL, brand image, and brand loyalty.

\section{Research model and hypotheses}

〈Figure 1〉 A conceptual model of the effect of PIL on consumers.

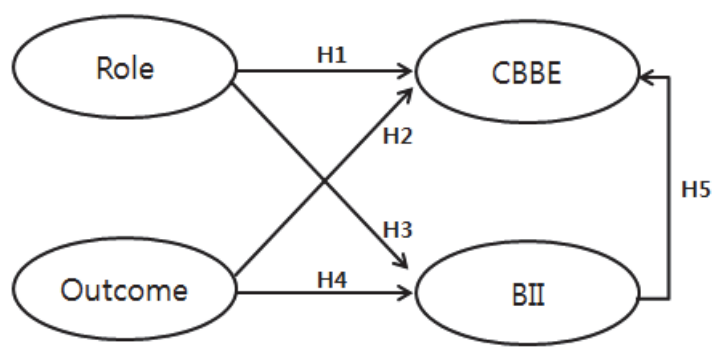

Figure 1 simply shows the structural model for PIL's effects on BII and CBBE, which presents the basic idea for the research hypotheses.

\subsection{CBBE and PIL}

Patents serve as an important output indicator of research and development activities, and are widely adopted in research concerning the relationship between patent counts and corporation performance (Bosworth and Rogers, 2002; Comanor and Scherer, 1969; Deng et al., 1999). Litigation PR theories argue that information about litigation can affect a firm's reputation, so it is highly possible that PIL directly affects consumers' attitudes toward a brand. Along with the PIL information that has spread quickly and widely, the relationship between patents and CBBE seems to be more direct and clear. Litigation PR is needed more for the defendant 
than for the plaintiff (Hantler et al., 2004); that is, customers who receive information from the media about litigation may have a more favorable perception of the plaintiff of PIL. Accordingly, this study assumes that plaintiff image in PIL can affect consumers positively. However, excessive filing of litigation may lead to warlike or negative images for the plaintiff and may contribute to counter-effects on consumers' attitudes. Therefore, this study hypothesizes that the plaintiff image will have an influence on $\mathrm{CBBE}$, and if the hypothesis is passively supported, there exists an indication that PIL benefits a brand. However, if the hypothesis is negatively supported, it is an indication that excessively engaging in litigation could damage a brand. It is worth noting that since the lengthy PIL process and transnational characteristics exist, it may be difficult for customers to completely understand the process, as they may only receive partial information. Therefore, this study investigates how consumers perceive the plaintiff himself, rather than using real objective data of the PIL's plaintiff. Also, this study assumes that people are familiar with the brands and PIL before the study, so the CBBE dimension of brand awareness and association are excluded in this part.

H1-1: Perceived plaintiff image will have an influence on brand perceived quality.

H1-2: Perceived plaintiff image will have an influence on brand loyalty.
On the other hand, according to McCracken (2003), since court judgments are public record, there is a risk that publicity may harm the name of the auditing firm. That is, judgments may affect the public when evaluating a firm or a brand. A winner of PIL may receive a higher evaluation and may be labeled as an innovator or pioneer, while the loser may receive a low evaluation in the public eye as being the infringer or copycat. Thus, this study assumes the second hypothesis below when examining the outcome's effect on customers:
H2-1: Perceived winner image will have a positive influence on brand perceived quality.

H2-2: Perceived winner image will have a positive influence on brand loyalty.

\subsection{Brand innovation image and PIL}

R\&D spending is positively related to patents. Internal research capabilities, particularly those with a strong basic research component, are key to enabling a firm to generate creative outputs (Cardinal and Hatfield, 2000; Bogner and Bansal, 2007; Artz, 2008). As mentioned above, patents are an important output indicator of re- $^{-}$ search and development, and can easily connect to innovation. With the emergence of PIL, patents as a form of litigation seem to affect BII more directly than the form of a product. That is, consumers' evaluations of a brand as 
innovative or not are no longer based on the brand's products. A patent as a form of litigation can directly affect consumers' attitudes and become one standard when consumers evaluate a brand innovation. Therefore, instead of comparing a company's financial performance and patent volumes, this study focuses on the brand innovative image from the viewpoint of the customer and assumes that widespread PIL information may affect consumers' evaluations of brand innovation directly. Moreover, BII also can be seen as a mediator in the relationship between PIL and CBBE; that is, PIL may first affect the perceived BII, and then BII may affect CBBE. Thus, this study has two hypotheses related to BII and one hypothesis on the mediator effect of BII, as below.

H3: Perceived plaintiff image will have a positive influence on brand innovation image.

H4: Perceived winner image will have a positive influence on brand innovation image.

H5: Brand innovation image will have a positive influence on $C B B E$.

H5-1: Brand innovation image will have a positive influence on brand awareness and association.

H5-2: Brand innovation image will have a positive influence on brand perceived quality.

H5-3: Brand innovation image will have a positive influence on brand loyalty.

\subsection{Research model}

To conduct research based on the structure above, this study first separates collected data into two groups, knowledgeable and unknowledgeable groups about PIL (i.e., people who know about PIL and those who do not). For the hypotheses related to the PIL role (plaintiff or defendant) and outcome (winner or loser), there is an assumption that people are familiar with PIL. Therefore, this study only uses data from the group that is familiar with PIL in the research model to identify the effects of the PIL role and outcome on CBBE and BII. In addition, in its comparison of Apple and Samsung, this study also provides evidence as to which brand is affected more by PIL. Figure 2 is the specific research model.

\section{Research methodology}

\subsection{Brand selection}

This study selects two brands as the parties of PIL: Apple and Samsung. For this selection, the consumer's familiarity with and knowledge of the brands are considered. Consumers who are not familiar with the brands and PIL may not be able to respond to the questions asked 
〈Figure 2〉 Research model for PIL effects.

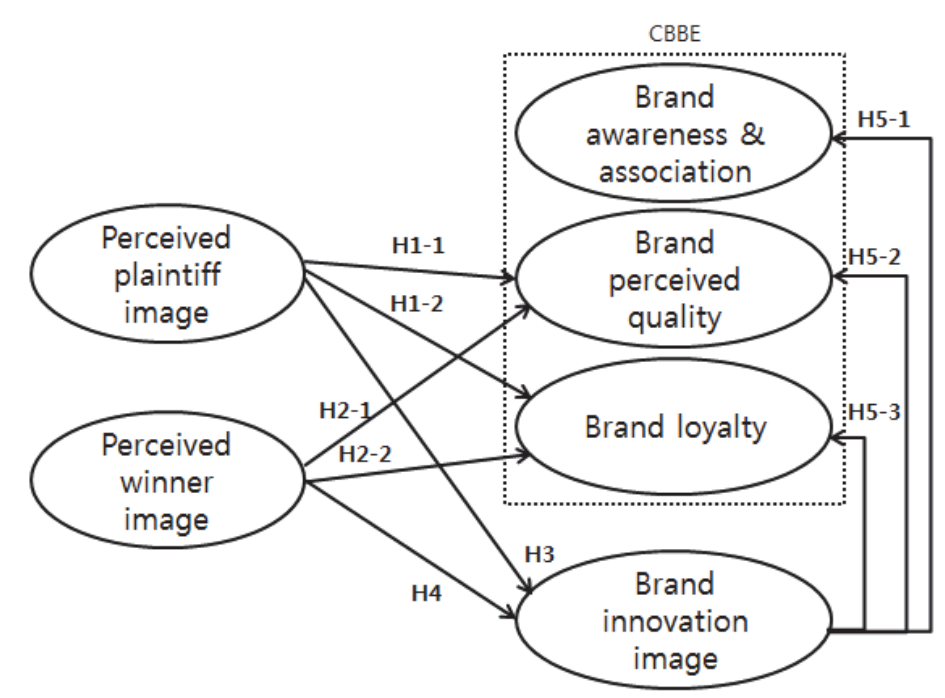

in this study. Also, according to the latest research from Strategy Analytics, Apple and Samsung recently overtook the long-time volume leader Nokia for the top two spots in the global smartphone market. In addition, PIL between these two brands has been the most prevalent and lasting (Netzer and Sambandam, 2014(b)), and the information from the PIL between these two brands is widespread via various types of media.

\subsection{Measurement}

This study uses questionnaire items that operationalize several types of variables: two dependent variables (CBBE and BII), three independent variables, and the outcome of PIL and role in PIL variables, which are concurrently measured based on questionnaire items.
For the measurement of PIL's outcome (win or loss) and role in PIL (plaintiff or defendant), since the information on PIL between Apple and Samsung in the public media is too complicated to understand wholly, and the lengthy PIL process and transnational cases easily confuse customers as well, this study investigates consumers' 'perceived' role and outcome rather than determining the 'real' ones by analyzing objective data. In order to reflect the respondents' certainty of their answers, this study uses a five-point scale, with 1 meaning that Apple is the PIL's winner/plaintiff for sure, and 5 meaning that Samsung is the PIL's winner/plaintiff for sure.

Among several brand equity models, this study uses the one constructed by Aaker (1992), which is the most commonly cited. This model has been empirically tested in a number of pre- 
vious studies (Yoo et al., 2000; Kim and Kim, 2004; Atilgan et al., 2005). Based on Aaker's brand equity model (1992), the model in this study includes an 11-item scale with three dimensions, including brand loyalty, perceived quality, brand awareness and associations, and uses a five-point Likert agreement scale for each item. In addition, in order to compare Apple and Samsung's CBBE, this study investigates their degree respectably and includes a total of 22 items.

By correlating the consumers' perceptions of these brands with where they compare on the innovation scale, this study uses Thomas' six indices (be a pioneer; make my life easier, create a buzz, be approved by my peers, be granted a reason to trust you) to investigate consumers' perceived BII for Apple and Samsung. A total of 12 items with a five-point Likert agreement scale for each item were used.

\subsection{Survey and sampling}

An international online survey was conducted to assess consumers' evaluation of brands involved with PIL. This study used papers and emails and also utilized social networks, such as Facebook, and smartphone applications to increase the response rate. In addition, for the purpose of this study, respondents of this study's survey were required to know what the smart products were and be aware of both Apple and Samsung brands. The study collected data from
April 20 to May 20, 2012. The URL address of the Internet survey website was spread by smartphone applications, such as Kakaotalk or Whatsapp, and posted on the designated smart product-related online communities' websites. The survey questionnaires were translated into Korean, Simplified Chinese and Traditional Chinese.

\section{$V$. The results of the analyses}

The main purpose of this study is to explore the relationship between PIL and consumers. More specifically, this study examines the influence of PIL on CBBE/BII. First, the results show the frequency analysis, reliability check, and discrimination check among the variables. Next, this study tests a causal path from PIL's outcomes/roles to CBBE/BII with a structural equation model to identify whether the hypotheses that we assumed are supported. Lastly, this study discusses the findings of the surveys that support or explain the quantitative results and discovers uncovered effects of PIL.

\subsection{The characteristics of survey respondents}

An international sample was drawn from a smart product-related website and three universities located in China, Taiwan and Korea. A total of 403 questionnaires were received 
from voluntary participants both through the website and on campus. Questionnaires with missing data or invalid responses (e.g., answering all questions with the same answer) were eliminated and not used for statistical analysis purposes, so only 382 individuals' responses formed the data of this analysis. Table 1 illustrates the demographic information of the survey respondents.
As shown in Table 1, 17.1\% $(\mathrm{N}=65)$ of $\mathrm{re}^{-}$ spondents weren't aware of Apple-Samsung PIL (unknowledgeable group), while 82.8\% ( $\mathrm{N}=317)$ of respondents were aware of PIL (knowledgeable group). Among the knowledgeable group, over $50 \%$ of the respondents thought Apple was the plaintiff, while only $17.8 \%$ thought Samsung was the plaintiff. When it came to PIL's outcome, nearly half of the respondents

〈Table 1〉 Frequency Analysis of Demographics

\begin{tabular}{|c|c|c|c|}
\hline \multicolumn{2}{|c|}{ Frequency Analysis } & \multirow{2}{*}{$\begin{array}{c}\mathrm{N} \\
228\end{array}$} & \multirow{2}{*}{$\begin{array}{c}\% \\
59.7 \\
\end{array}$} \\
\hline & Female & & \\
\hline & Male & 154 & 40.3 \\
\hline \multirow{4}{*}{ Age } & Under 20 & 49 & 12.8 \\
\hline & $21-30$ & 297 & 77.7 \\
\hline & $31-40$ & 32 & 8.4 \\
\hline & Over 40 & 4 & 1.0 \\
\hline \multirow{6}{*}{ Nationality } & Taiwan & 151 & 39.5 \\
\hline & Korea & 88 & 23.0 \\
\hline & China & 78 & 20.4 \\
\hline & Europe & 13 & 3.4 \\
\hline & America & 25 & 6.5 \\
\hline & Other countries & 27 & 7.1 \\
\hline \multirow{4}{*}{ Education } & Less than high school & 22 & 5.8 \\
\hline & High school & 20 & 5.2 \\
\hline & College & 236 & 61.8 \\
\hline & Graduate school or higher & 104 & 27.2 \\
\hline \multirow{2}{*}{ Using smart products or not } & Using & 318 & 83.2 \\
\hline & Not & 64 & 16.8 \\
\hline \multirow{7}{*}{ Brand of smart product } & Apple & 107 & 28.0 \\
\hline & Samsung & 73 & 19.1 \\
\hline & Other brand & 106 & 27.7 \\
\hline & Apple and Samsung & 11 & 2.9 \\
\hline & Apple and other brand & 12 & 3.1 \\
\hline & Samsung and other brand & 6 & 1.6 \\
\hline & All & 6 & 1.6 \\
\hline
\end{tabular}


(48.3\%, $N=153$ ) thought that the winner had been or would be Apple, while 18.7\% of the respondents didn't know, and only 13\% thought that Samsung had been or would be the winner.

\subsection{Construct validation and reliability assessment}

The reliability of factors and model fit are gauged to assess construct validation of the proposed model. Goodness of fit $\left(\mathrm{x}^{2} / \mathrm{df}\right)$ is under 3, and values higher than 0.90 on CFI,
GFI, and NFI are generally considered representative of a well-fitting model (Hu and Bentler, 1999). For the RMSEA, values in the range of 0.05 to 0.08 are an acceptable fit (Browne \& Cudeck, 1992). This study first conducts confirmatory factor analysis (CFA) displayed in Table 2, which supports the internal validity and reliability of the relationships among brand awareness, association, perceived quality, brand loyalty and BII. In addition, Table 3 shows that the correlation squared coefficients are lower than the average variance extracted (AVE), which

〈Table 2〉 CFA for Apple and Samsung

\begin{tabular}{|c|c|c|c|c|c|c|c|c|c|c|c|}
\hline & Item & $\begin{array}{c}\text { Est. } \\
\text { Apple }\end{array}$ & $\begin{array}{c}\text { Est. } \\
\text { Sam** }\end{array}$ & $\begin{array}{l}\text { t-value } \\
\text { Apple }\end{array}$ & $\begin{array}{l}\text { t-value } \\
\text { Sam }\end{array}$ & $\begin{array}{c}\text { S.C. } \\
\text { Apple }\end{array}$ & $\begin{array}{l}\text { S.C. } \\
\text { Sam }\end{array}$ & $\begin{array}{l}\text { C.R. } \\
\text { Apple }\end{array}$ & $\begin{array}{l}\text { C.R. } \\
\text { Sam }\end{array}$ & $\begin{array}{l}\text { A.V.E } \\
\text { Apple }\end{array}$ & $\begin{array}{l}\text { A.V.E } \\
\text { Sam }\end{array}$ \\
\hline \multirow{4}{*}{$\begin{array}{l}\mathrm{A} \\
\mathrm{W} \\
\mathrm{A} \\
\mathrm{S}\end{array}$} & 1 & 1.000 & 1.000 & - & - & 0.760 & 0.748 & \multirow{4}{*}{0.904} & \multirow{4}{*}{0.702} & \multirow{4}{*}{0.701} & \multirow{4}{*}{0.412} \\
\hline & 2 & 0.958 & 0.746 & 11.746 & 8.823 & 0.721 & 0.590 & & & & \\
\hline & 3 & 0.696 & 0.922 & 12.302 & 9.260 & 0.760 & 0.642 & & & & \\
\hline & 4 & 0.686 & 0.542 & 11.386 & 8.667 & 0.697 & 0.550 & & & & \\
\hline \multirow{2}{*}{$\mathrm{PQ}$} & 1 & 1.000 & 1.000 & - & - & 0.826 & 0.899 & \multirow{2}{*}{0.865} & \multirow{2}{*}{0.860} & \multirow{2}{*}{0.760} & \multirow{2}{*}{0.754} \\
\hline & 2 & 0.990 & 0.822 & 15.145 & 15.556 & 0.886 & 0.809 & & & & \\
\hline \multirow[t]{5}{*}{ BL } & 1 & 1.000 & 1.000 & - & - & 0.889 & 0.866 & \multirow{5}{*}{0.863} & \multirow{5}{*}{0.883} & \multirow{5}{*}{0.559} & \multirow{5}{*}{0.607} \\
\hline & 2 & 0.950 & 0.897 & 21.350 & 17.075 & 0.867 & 0.791 & & & & \\
\hline & 3 & 0.933 & 0.877 & 20.822 & 18.133 & 0.856 & 0.828 & & & & \\
\hline & 4 & 0.947 & 0.945 & 19.768 & 18.364 & 0.833 & 0.839 & & & & \\
\hline & 5 & 0.831 & 0.878 & 15.629 & 15.540 & 0.727 & 0.751 & & & & \\
\hline \multirow[t]{4}{*}{ BI } & 1 & 1.000 & 1.000 & - & - & 0.717 & 0.661 & \multirow{4}{*}{0.755} & \multirow{4}{*}{0.784} & \multirow{4}{*}{0.435} & \multirow{4}{*}{0.454} \\
\hline & 2 & 0.748 & 0.884 & 9.769 & 11.885 & 0.628 & 0.701 & & & & \\
\hline & 3 & 0.839 & 0.697 & 8.802 & 10.363 & 0.561 & 0.626 & & & & \\
\hline & 4 & 0.982 & 0.779 & 10.544 & 11.407 & 0.684 & 0.792 & & & & \\
\hline
\end{tabular}

Model fit for Apple $\mathrm{X}^{2} / \mathrm{df}=2.72, \mathrm{GFI}=0.901, \mathrm{NFI}=0.890, \mathrm{CFI}=0926$, RMSEA $=0.074$

Model fit for Samsung $\mathrm{X}^{2} / \mathrm{df}=2.474, \mathrm{GFI}=0.908, \mathrm{NFI}=0.889, \mathrm{CFI}=0.930, \mathrm{RMSEA}=0.069$

Est. =Estimate, S.C. =Standardized coefficient, C.R. = Construct reliability, A.V.E = Average variance extracted,

$\mathrm{AWAS}=$ Brand awareness and association, $\mathrm{PQ}=$ Brand perceived quality, $\mathrm{BL}=$ Brand loyalty,

$\mathrm{BI}=$ Brand innovation image, Sam** $=$ Samsung brand 
〈Table 3〉 Discriminant Validity for Apple and Samsung

\begin{tabular}{ccccccccc}
\hline & \multicolumn{4}{c}{ Apple } & \multicolumn{5}{c}{ Samsung } \\
\cline { 2 - 9 } & AWAS & PQ & BL & BI & AWAS & PQ & BL & BI \\
\hline AWAS & $0.701^{*}$ & & & $0.412^{*}$ \\
\hline PQ & 0.220 & $0.760^{*}$ & & & 0.336 & $0.754^{*}$ & \\
\hline BL & 0.120 & 0.381 & $0.559^{*}$ & & 0.206 & 0.304 & $0.607^{*}$ & \\
\hline BI & 0.336 & 0.596 & 0.397 & $0.435^{*}$ & 0.292 & 0.610 & 0.309 & $0.454^{*}$ \\
\hline
\end{tabular}

$*=$ A.V.E

means that the discriminant validity is also satisfied (Browne and Cudeck, 1992).

\subsection{Path estimates}

According to Table 4, $\mathrm{H} 1$ and $\mathrm{H} 2$ are concerned with PIL to the brand perceived quality and brand loyalty as a consequence of the outcome or role in the Apple-Samsung PIL. That is, if the customers think Apple is the plaintiff or has won the PIL, Apple will have highly perceived quality and loyalty. Similar to Apple's brand, if customers think the plaintiff or win- ner is Samsung, Samsung will have highly perceived quality and loyalty. H3 and H4 address the relationship between PIL and BII, and H5 emphasizes BII's mediating role in the PIL-CBBE relationship. In other words, PIL's role or outcome may first affect BII, and then BII affects CBBE. However, there is still the possibility that direct and indirect effects are shown simultaneously.

On the other hand, only H1-2 is negatively and weakly supported with a $\mathrm{p}^{-}$-value under 0.1 in the Samsung case. That is, the plaintiff image has a certain negative influence on Samsung's

〈Table 4〉 Path Estimates for Apple and Samsung

\begin{tabular}{ccccccc}
\hline & Apple S.C & Samsung S.C. & Apple C.R. & Samsung C.R & Apple Sig. & Samsung Sig. \\
\hline H1-1 & 0.028 & -0.065 & 0.581 & -1.430 & 0.561 & 0.153 \\
\hline H1-2 & -0.031 & -0.089 & -0.628 & -1.740 & 0.530 & $0.082^{*}$ \\
\hline H2-1 & 0.023 & -0.06 & 0.468 & -0.113 & 0.640 & 0.910 \\
\hline H2-2 & 0.118 & 0.016 & 2.334 & 0.285 & $0.002^{* * *}$ & 0.776 \\
\hline H3 & -0.057 & 0.035 & -0.893 & 0.585 & 0.372 & 0.558 \\
\hline H4 & 0.235 & 0.371 & 3.643 & 5.621 & $* * *$ & $* * *$ \\
\hline H5-1 & 0.573 & 0.614 & 7.466 & 6.740 & $* * *$ & $* * *$ \\
\hline H5-2 & 0.812 & 0.827 & 10.016 & 9.633 & $* * *$ & $* * *$ \\
\hline H5-3 & 0.642 & 0.602 & 9.285 & 7.683 & $* * *$ & $* * *$ \\
\hline$* \mathrm{p}<0.1,{ }^{* *} \mathrm{p}<0.05,{ }^{* * *} \mathrm{p}<0.01$ & & & & &
\end{tabular}


〈Table 5〉 Summary of Hypothesis Findings of Structural Equation Model

\begin{tabular}{|c|c|}
\hline Hypothesis & Supported \\
\hline H1-1. Perceived plaintiff image will have a positive influence on Brand Perceived Quality. & No \\
\hline H1-2 Perceived plaintiff image will have a positive influence on Brand Loyalty. & Partly Yes \\
\hline H2-1. Perceived winner image will have a positive influence on Brand Perceived Quality. & No \\
\hline H2-2. Perceived winner image will have a positive influence on Brand Loyalty. & Partly Yes \\
\hline H3. Perceived plaintiff image will have a positive influence on brand innovation image. & No \\
\hline H4. Perceived winner image will have a positive influence on brand innovation image. & Yes \\
\hline H5-1. BII will have a positive influence on Brand Awareness and Association. & Yes \\
\hline H5-2. BII will have a positive influence on Brand Perceived Quality. & Yes \\
\hline H5-3. BII will have a positive influence on Brand Loyalty. & Yes \\
\hline
\end{tabular}

brand loyalty. H3 is shown as not significant in either brand, with a $\mathrm{p}$-value over 0.1 , so that PIL's plaintiff image has no impact on BII. However, H4 is strongly accepted with a significance level of 0.01 for both the Apple and Samsung brands, which means that PIL's outcome strongly affects BII. Moreover, H5-1, H5-2, and H5-3 are strongly accepted, so BII's mediating role is also confirmed. Table 5 provides the hypothesis test results for the structural equation model.

\section{Conclusions and implications}

The results of the structural equation model provide insights into the relationship between PIL and customers by investigating CBBE/BII within their perceived PIL outcome/role. A PIL's outcome strongly affects BII, which is valued by consumers. Consumers spend more time evaluating brands with a more innovative image, and they also participate heavily in creating buzz around the innovative brand they love. These behaviors lead to higher CBBE, which is confirmed by Hypothesis 5. A more innovative image contributes to higher brand awareness/ association, brand perceived quality, and brand loyalty. Furthermore, PIL's outcome affects CBBE more directly for the brands that emphasize creativity or innovation heavily and have a more positive BII. However, it is worth noting that plaintiff image seems to have a more negative effect than what was thought; it was originally believed to have a positive effect on brand loyalty.

From an academic perspective, existing PIL researches have mainly identified the monetary loss or gain accrued from the patents. For example, Samsung and Apple have estimated the value consumers place on specific patented product features, such as the touchscreen and software, by using conjoint analysis (Netzer and Sambandam, 
2014a). However, the values of certain features certainly depend upon perceived brand images. As a result, this study could improve the evaluation of patents considering not only the specific features of products but also perceived brand images that are formed by PIL.

This study has several key managerial contributions which are critical to marketing perspectives. The findings allow the marketers and managers to make better decisions in the valuation of patents when engaging in PIL. First, the PIL marketing strategy can be used for consumers in appreciating brands related to consumer products, including the high-tech industry. On the other hand, it also reminds PR managers to pay more attention to PIL filed by competitors and prepare for litigation public relations management. Businesses spend of millions of dollars in marketing deals each year to strengthen their brands and increase the potentiality of growing their companies. By engaging in PIL, brand awareness, association, and BII will be improved. Second, PIL can be strategically used to differentiate from competitors to gain competitive advantages. Since consumers will have a wider gap of CBBE and brand innovation image after they are aware of PIL, this can effectively enable firms to differentiate from its competitors in the process. However, there are still some risks when engaging in PIL. Above all, if a brand loses a PIL case, either its innovation image or CBBE may decrease to an even lower degree than before. Also, since plaintiff image sometimes results in a negative influence on brand loyalty, companies should engage in PIL with caution and avoid excessively filing lawsuits. Moreover, PIL has more influence on a brand with a high innovation image, so an innovative brand is more suitable for using PIL as a marketing strategy. Third, practitioners should pay more attention to brand innovation image. As shows above, brand innovation image plays key role in developing CBBE. Ironically, perceived winner image in PIL contributes to brand innovation image although consumers may do not know which company really won. This result implies that the image of seemingly winner may be a more important factor than at least building $\mathrm{CBBE}$ by consumers. Thus, practitioners need to manage information through mass media as well as information flow through social network services.

This study also includes some limitations. First, we deal with cases only between Samsung and Apple. Greater external validity would result across a greater diversity of brands and PIL cases, including those engaged in the consumer product industry. Furthermore, the respondents are restricted to young people since smart product users tend to be young, and the findings may be different across ages. Also, the respondents are Chinese and Korean who may be regarded to represent consumers' perspectives in Asia. However, this sampling could not reflect other stances such as European and American. For future research, other brands involved in PILs could be investigated and compared with this 
study. Moreover, various factors, for example, the differences among consumers such as nationality and knowledge about PIL and IT products should be considered so as to elaborate marketing effects on PIL. Another focus could be measurement PIL's marketing effect across a more extensive age range. Nationalism or brand loyalty levels consumers already have may seem to influence on the effects of PIL. Thus, future researches could bring them into the research structure to reveal the interaction of these factors.

〈Received October 1. 2015〉

〈Revised March 23. 2016〉

〈Accepted March 28. 2016〉

\section{References}

Aaker, David A. (1992), "The Value of Brand Equity," Journal of Business Strategy, 13 (4), 27-32.

Ailawadi, Kusum L., Donald R. Lehmann, and Scott A. Neslin (2003), "Revenue Premium as an Outcome Measure of Brand Equity," Journal of Marketing, 67(4), 1-17.

Ambler, T., C. B. Bhattacharya, Julie Edell, Kevin L. Keller, Katherine N. Lemon, and Vikas Mittal. (2002), "Relating Brand and Customer Perspectives on Marketing $\mathrm{Ma}^{-}$ nagement," Journal of Service Research, 5(1), 13-25.
Artz, Kendall W. (2008), “Corporate Entrepreneurship: A Longitudinal Examination of Innovative Efficiency, Patents, and Firm Performance (SUMMARY)," Frontiers of Entrepreneurship Research, 28(19), 6.

Atilgan, E., Safak Aksoy, and Serkan Akinci (2005), "Determinants of the Brand Equity: A Verification Approach in the Beverage Industry in Turkey," Marketing Intelligence \& Planning, 23(3), 237-248.

Bessen, J. E., and Michael J. Meurer (2008), "The Private Costs of Patent Litigation," Boston University School of Law Working Paper, 2nd Annual Conference on Empirical Legal Studies Paper, 7-8.

Bessen, J. E., Peter Neuhausler, John L. Turner and Jonathan Williams (2015), "Trends in Private Patent Costs and Rents for PubliclyTraded United States Firms," Public Law Research Paper, 13-24, Boston University School of Law, Boston.

Bloom, Nicholas and John V. Reenen (2002), "Patents, Real Options and Firm Performance," Economic Journal, 112(478), 97-116. Bogner, Willam C., and Pratima Bansal (2007), "Knowledge Management as the Basis of Sustained High Performance," Journal of Management Studies, 44(1), 165-188.

Bosworth, Derek and Mark Rogers (2002), "Market Value, R\&D and Intellectual Property: An Empirical Analysis of Large Australian Firms," Economic Record, 77(239), 323-337. Browne, Michael W., and Robert Cudeck (1992), 
"Alternative Ways of Assessing Model Fit," Sociological Methods \& Research, 21(2), 230-258.

Cardinal, Laura B., and Donald E. Hatfield (2000), "Internal Knowledge Generation: The Research Laboratory and Innovative Productivity in the Pharmaceutical Industry," Journal of Engineering and Technology Management, 17(3-4), 247-271.

Chien, Collen V. (2008), "Of Trolls, Davids, Goliaths, and Kings: Narratives and Evidence in the Litigation of High-Tech Patents," NCL Review, 87, 1571.

Cobb-Walgren, Cathy J., Cynthia A. Ruble, and Naveen Donthu (1995), "Brand Equity, Brand Preference, and Purchase Intent," Journal of advertising, 24(3), 25-40.

Comanor, William S., and Frederic M. Scherer (1969), "Patent Statistics as a Measure of Technical Change," Journal of Political Economy, 392-398.

Cremers, Katrin (2007), “Incidence, Settlement and Resolution of Patent Litigation Suits in Germany," PhD Thesis, University of Mannheim.

Deng, Z., Baruch Lev, and Francis Narin (1999), "Science and Technology as Predictors of Stock Performance," Financial Analysts Journal, 55(3), 33-47.

Fitzpatrick, Kathy R., and Maureen S. Rubin (1995), "Public Relations vs. Legal Strategies in Organizational Crisis Decisions," Public Relations Review, 21(1), 21-33.
Gibson, Dirk C., and Mariposa E. Padilla (1999), "Litigation Public Relations Problems and Limits," Public Relations Review, 25(2), 215-233.

Haggerty, James F. (2004), "Putting the Best Face on It: Litigation PR in the Era of 24-Hour Cable News," Business Law Today, 16-20.

Hantler, Steven B., Victor E. Schwartz, and Phil S. Goldberg (2004), "Extending the Privilege to Litigation Communications Specialists in the Age of Trial by Media," CommLaw Conspectus, 13, 7.

Hong, Soonwoo (2009), Claiming What Counts in Business: Drafting Patent Claims With a Clear Business Purpose, WIPO

Hu, Li-tze and Peter M. Bentler (1999), "Cutoff Criteria for Fit Indexes in Covariance Structure Analysis: Conventional Criteria Versus New Alternatives," Structural Equation Modeling: A Multidisciplinary Journal, 6(1), 1-55.

Jun, Sung Youl., Tae Wook Ju., and Do Hyung Kim (2009), "Effects of Brand Performance Information on Brand Evaluation: The Moderating Roles of Personal Characteristics," Asia Marketing Journal, 11(2), 149-172.

Keller, Kevin L. (1993), "Conceptualizing, Measuring and Managing Customer-Based Brand Equity," Journal of Marketing; 57(1), 1-22. Keller, Kevin L., and Donald R. Lehmann (2006), "Brands and Branding: Research Findings and Future Priorities," Marketing Science, 
25(6), 740-759.

Kim, WooGon and Hong-Bumm Kim (2004), "Measuring Customer-Based Restaurant Brand Equity," Cornell Hospitality Quarterly, 45(2), 115-131.

Kortum, Samuel and Josh Lerner (2000), “Assessing the Contribution of Venture Capital to Innovation," RAND Journal of Economics, 31(4), 674-692.

Lee, Won-jun and Han-suk Lee (2012), "Consumer's Negative Brand Rumor Acceptance and Rumor Diffusion," Asia Marketing Journal, 14(2), 65-96.

Lemley, Mark A. (2005), "Patenting Nanotechnology," Stanford Law Review, 52(2), 601-630.

Mansfield, E., Mark Schwartz, and Samuel Wagner (1981), "Imitation Costs and Patents: An Empirical Study," The Economic Journal, 91(364), 907-918.

Mazzoleni, R., and Nelson R. Richard (1998), "The Benefits and Costs of Strong Patent Protection: A Contribution to the Current Debate," Research policy, 27(3), 273-284.

McCracken, Susan A. (2003), “Auditors' Strategies to Protect Their Litigation Reputation: A Research Note," Journal of Practice \& Theory, 22(1), 165-179.
Netzer, Oded and Rajan Sambandam (2014a), “Apple vs. Samsung: The \$2 Billion Case," Columbia Case Works, October (20), 1-7. Netzer, Oded and Rajan Sambandam (2014b), "Epilogue: Apple vs. Samsung: The \$2 Billion Case," Columbia Case Works, October (15), 1-3.

Pisano, G. (2006), "Profiting from Innovation and the Intellectual Property Revolution," Research Policy, (35), 1122-1130.

Rudy, Bruce C., and Stephanie L. Black (2015), "Attack or Defend? The Role of Institutional Context on Patent Litigation Strategies," Journal of Management, 20(10), $1-24$.

Somaya, Deepak (2003), "Strategic Determinants of Decisions Not to Settle Patent Litigation," Strategic Management Journal, 24(1), 17-38. Thomas, P. (2008). How Consumers Love Innovative Brands and Why, World Advertising Research Center

Yoo, Boonghee, Naveen Donthu, and Sungho Lee (2000), “An Examination of Selected Marketing Mix Elements and Brand Equity," Journal of the Academy of Marketing Science, 28(2), 195-211.

PWC(2011), 2011 Patent Litigation Study: Patent Litigation Trends as the America Invents Act Becomes Law(www.pwc.com/us/forensic) 